\title{
STUDI PENAMBATAN MOLEKULER SENYAWA FLAVONOID DAUN JAMBU BIJI (Psidium guajava L.) TERHADAP SARS-CoV-2 3CL PROTEASE
}

\author{
MOLECULAR DOCKING STUDY OF FLAVONOID \\ COMPOUNDS THE GUAVA LEAVES (Psidium guajava L.) \\ AGAINST SARS-CoV-2 3CL PROTEASE
}

\author{
Rizki Rahmadi Pratama ${ }^{1}$, Andika $^{1}$, Siti Nashihah ${ }^{1}$ \\ Fakultas Farmasi, Universitas Muhammadiyah Banjarmasin \\ Jl. Gubernur Sarkawi, Handil Bakti, Kalimantan Selatan. \\ Email correspondent: andika@umbjm.ac.id
}

Submitted : 11 Juli 2021 Reviewed : 21 Agustus 2021 Accepted: 6 September 2021

\begin{abstract}
ABSTRAK
Coronavirus Disease 2019 (COVID-19) yang disebabkan oleh Severe Acute Respiratory Syndrome Coronavirus 2 (SARS-CoV-2) yang dimana COVID-19 ini telah menjadi wabah secara global. Beberapa penelitian yang dilakukan secara in-silico daun jambu biji (Psidium guajava L.) terbukti memiliki aktivitas dalam menghambat main protease/3CL Protease dari beberapa protein yang tersedia didalam protein data bank. Tujuan dari penelitian ini yaitu untuk mengetahui potensi senyawa flavonoid daun jambu biji (Psidium guajava L.) sebagai penghambat 3CL Protease pada protein dengan PDB ID : 6M2N menggunakan uji penambatan molekul. Pengujian dalam penelitian ini meliputi uji Lipinski, penambatan molekul, dan prediksi ADMET. Metode yang digunakan adalah penambatan molekul dengan program AutoDockTools 1.5.6. Hasil dari 31 senyawa yang telah melalui penambatan molekul beberapa senyawa uji diantaranya memiliki nilai penambatan molekuler dalam bentuk (energi ikat bebas $(\Delta G)$ ) terbaik yaitu senyawa Epicatechin-3-O-Gallate dengan nilai $-9,08 \mathrm{kcal} / \mathrm{mol}$, glycitin dengan nilai $-8,84 \mathrm{kcal} / \mathrm{mol}$, dan ononin $-8,51 \mathrm{kcal} / \mathrm{mol}$. Epicatechin-3-O-Gallate dinilai memiliki potensi yang besar sebagai penghambat 3CL Protease karena memiliki kekuatan dan kestabilan ikatan yang tinggi saat ditambatkan pada protein target. Residu asam amino GLU 166, LEU 141, GLY 143 dan CYS 145 merupakan residu yang paling banyak berkontribusi dalam pembentukan ikatan hidrogen.
\end{abstract}

Kata kunci : COVID-19, Flavonoid, Psidium guajava L, Penambatan Molekul, AutoDock4

\begin{abstract}
Corona Virus Disease 2019 (COVID-19) caused by Severe Acute Respiratory Syndrome Corona Virus 2 (SARS-CoV-2), which COVID-19 has become a global epidemic. Several studies conducted in-silico guava leaves (Psidium guajava L.) were shown to have activity in inhibiting the main protease/3CL protease. Protease from several proteins available in the protein data bank. The purpose of this study was to see the potential of the guava leaf flavonoid compound (Psidium guajava L.) as an inhibitor of 3CL Protease on protein with PDB ID: 6M2N using the molecular docking test. The tests in this study include the Lipinski test, molecular docking, and
\end{abstract}


ADMET prediction. The method used is molecular docking with the AutoDockTools 1.5.6 program. The results of the 31 compounds that had gone through the molecular docking of several test compounds included the best molecular docking value in the form of free binding energy $(\Delta \mathrm{G})$ Epicatechin-3-O-Gallate compound with value of $9.08 \mathrm{kcal} / \mathrm{mol}$, glycitin with value of $-8.84 \mathrm{kcal} / \mathrm{mol}$, and ononin with value -8.51 $\mathrm{kcal} / \mathrm{mol}$. Epicatechin-3-O-Gallate has great potential as 3CL protease inhibitor because it has high strength and stability bonds when tethered to the target protein. The amino acid residues of GLU 166, LEU 141, GLY 143, and CYS 145 are the residues that most contribute to the ordering of hydrogen bonds.

Keywords: COVID-19, Flavonoid, Psidium guajava L, Molecular Docking, AutoDock4

\author{
Penulis Korespondensi : \\ Rizki Rahmadi Pratama \\ Universitas Muhammadiyah Banjarmasin \\ Jl. Gubernur Sarkawi, Handil Bakti, Kalimantan Selatan \\ Email : andika@umbim.ac.id
}

\title{
PENDAHULUAN
}

Coronavirus disease 2019 (COVID-19) yang diakibatkan oleh Severe Acute Respiratory Syndrome Coronavirus-2 (SARS-CoV-2) dimana penyakit yang menyerang saluran pernafasan akut ini telah meyebar secara besar ke seluruh bagian dunia semenjak akhir tahun 2019. Coronavirus (CoV) merupakan virus yang memiliki ribonucleid acid (RNA) dimana jenis RNA yang dimiliki oleh virus ini adalah single-stranded RNA atau disebut juga RNA untai tunggal yang dilindungi struktur yang menyerupai selimut (enveloped structure) dan tersusun oleh beberapa bagian penting dari stuktur coronavirus yaitu Spike (S), Membrane (M), Envelop (E), dan Nucleocapsid (N) (Prajapat et al., 2020).

Coronavirus memiliki ukuran diameter $60 \mathrm{~nm}$ sampai dengan $140 \mathrm{~nm}$ dengan spike di permukaan nya ketika dilihat menggunakan mikroskop elektor virus ini berbentuk seperti mahkota "crown" oleh karena alasan inilah virus ini dinamakan Virus corona (Bhatt et al., 2021). Coronavirus masuk kedalam ordo Nidovirales dengan sub ordo Cornidovirinae dan masuk dalam keluarga Coronaviridae dengan dua subfamili yaitu Letovirinae dan Orthocoronavirinae. Letovirinae termasuk genus Alphaletovirus sedangkan Orthocoronaviridae terbagi menjadi empat generasi yaitu Alphacoronavirus, Betacoronavirus, Gammacoronavirus dan Deltacoronavirus. Coronavirus menyebar sangat luas dan cepat beberapa tipe dari coronavirus yang menginfeksi manusia antara lain adalah 229E, NL63, OC43, HKU1, MERS, dan SARS (Helmy et al., 2020).

Infeksi dari SARS-CoV-2 ini dapat menimbulkan kerusakan suatu jaringan pada tubuh dan penurunan dari fungsi paru-paru bahkan terdapat beberapa kasus dapat menyebabkan kegagalan paru-paru maupun dapat menyebakan kemungkinan paling buruk yaitu kematian. Gejala dari COVID-19 yang paling sering ditemukan atau dirasakan adalah demam, batuk kering, rasa lelah, rasa nyeri pada otot dan sakit, hidung tersumbat, sakit tenggorokan maupun diare gejala ini biasanya dialami bersifat ringan dan muncul secara bertahap (Rauf et al., 2020).

Mekanisme dari virus ini masuk kedalam tubuh adalah virus akan menempel di reseptor nya yaitu ACE-2 reseptor lalu virus masuk ke dalam sel, genom RNA dari virus ini akan dikeluarkan ke sel sitoplasma kemudian ditranslasikan menjadi poliprotein dan protein struktural. Genom virus akan mulai untuk bereplikasi dimana replikasi ini dibantu oleh main protease (Mpro)/Cysteine like protease (3CL Pro). Glikoprotein yang berada dalam bagian virus yang baru terbentuk masuk ke dalam membran retikulum endoplasma. Kemudian terjadi pembentukan nukleokapsid yang tersusun dari genom RNA dan protein nukleokapsid. 
Partikel virus akan tumbuh didalam retikulum endoplasm. Pada fase akhir dari siklus hidup, vesikel yang mengandung partikel virus akan bergabung dengan membran plasma sebagai virus yang matang kemudian dilepaskan keluar dari membran menggunakan sistem eksositosis (Kakodkar et al., 2020).

Target primer atau utama obat yang menjadi fokus para ilmuwan saat ini merupakan Mpro (Main Protease), lantaran main protease atau protease utama dari SARS-CoV-2 memiliki kesamaan 96\% dengan SARS-CoV-1 dimana Sasaran utama COVID-19, M pro / 3CL pro (Huang et al., 2020) dimana enzim ini mempunyai peran penting dalam kelangsungan hidup dari coronavirus, mekanisme dari 3CL Protease yaitu dengan cara membantu dari proses replikasi dan transkripsi protein-protein pada saat proses siklus hidup coronavirus. Pentingnya peran main protease ini menjadikannya sebagai salah satu target penting dalam menemukan dan mendesain antivirus untuk COVID-19. Inhibisi atau penghambatan dari aktivitas enzim ini akan menyebabkan berkurang atau terhambatnya replikasi dari virus. Dalam tubuh Manusia tidak memiliki enzim protease yang sama dengan protease utama virus ini, maka oleh sebab itu inhibitor Mpro tidak akan menghasilkan efek toksik atau efek mematikan terhadap manusia. Lopinavir dan ritonavir dilaporkan senyawa obat yang memiliki aktivitas penghambatan main protease (Mpro). (Purwaniati \& Asnawi, 2020).

Tanaman yang akan dipakai adalah Daun jambu biji (Psidium guajava L.) dimana daun jambu biji kaya akan kandungan senyawa bioaktif misalnya asam galat, katekin, epikatekin, rutin, naringenin, dan kaemferol. Sebagian output riset telah membuktikan bahwa daun jambu biji mempunyai banyak sekali aktivitas farmakologi, diantaranya sebagai analgesik, antiinflamasi, antimikroba, hepatoprotektif, antikanker, antihiperglikemik, dan antioksidan. Daun jambu biji diketahui dapat menghambat aktivitas beberapa virus yaitu IHNV (infectious haematopoietic necrosis virus), OMV (oncorhyncus masou virus), dan YHV (yellow-head virus) (Joseph \& Priya, 2011)

Flavonoid adalah senyawa golongan bahan alam dengan sturuktur penyusun utama yaitu fenolik, Flavonoid banyak terdapat dalam tumbuhan dan flavonoid juga sering ditemukan dalam sayur-sayuran, buah-buahan, biji-bijian, kulit kayu, batang, akar maupun bunga. Flavonoid juga dilaporkan memiliki banyak aktivitas seperti antiinflamasi, antivirus, antioksidatif, antimutagenik dan antikarsinogenik (Panche et al., 2016). Salah satu senyawa flavonoid yaitu kaempferol menunjukan adanya aktivitas sebagai inhibisi atau penghambat dari aktivitas main protease (Mpro) dan protein spike (S) (Tallei et al., 2020).

Dilihat dari Clpro/Mpro yang berpotensi sebagai target pengobatan dari COVID-19, oleh sebab itu penelitian ini dilakukan dengan tujuan untuk mengetahui potensi dari senyawa flavonoid dari daun jambu biji (Psidium guajava L.) terhadap kemampuannya dalam inhibisi enzim Clpro/Mpro khususnya SARS-CoV-2 3CL Protease (PDB ID : 6M2N), diharapkan bahwa penelitian ini dapat menjadi sumber informasi tambahan yang dapat meningkatkan ilmu pengetahuan maupun membantu dalam penemuan obat untuk COVID-19 dengan memanfaatkan bahan alam yang berada disekitar kita.

\title{
METODE PENELITIAN
}

\begin{abstract}
Alat dan Bahan
Perangkat keras yang digunakan pada studi penambatan molekuler ini berupa laptop ASUS ROG GL-552VX dengan spesifikasi Prosesor Intel ${ }^{\circledR}$ CoreTM i7-6700HQ, RAM 12,0 gigabyte, Hard disk penyimpanan 1 terabyte, Solid-state Drive (SSD) $512 \mathrm{~Gb}$, CPU (Central Processing Unit) @2,60GHz (8CPUs) 2,59 GHz, raphic Card NVIDIA GeForce GDDR5 GTX950M dan sistem operating Microsoft ${ }^{\circledR}$ Windows ${ }^{\circledR} 10$ Pro dengan laptop yang terbuhung dengan jaringan internet. Software yang digunakan dalam penelitian ini yaitu Autodock 4.2.6 sebagai software untuk melakukan docking, proses minimisasi energi ligand, senyawa pembanding, senyawa uji menggunakan software Avogadro serta Swiss PDB Viewer digunakan untuk minimisasi dari protein target dalam penelitian ini, untuk visualisasi interaksi dari protein dan ligand menggunakan software Discovery Studio Visualizer,
\end{abstract}


PyMOL, dan Ligplot++, untuk screening Lipinski's rules of five menggunakan website SCFBio, sedangkan website pkCSM digunakan untuk melakukan prediksi ADMET.

\section{Jalannya Penelitian}

Jalannya penelitian ini dibagi menjadi beberapa langkah yaitu preparasi dari protein ligand, penambatan protein ligand dan terakhir melakukan prediksi dari ADMET

2. Preparasi protein ligan

Hal pertama dalam melakukan preparasi ini adalah mengunduh kompleks protein target pada RCSB situs protein data bank (PDB) dengan kode 6M2N. lalu setelah pengunduhan telah dilakukan penghapusan dari semua molekul air dari lingkungan protein, selanjutnya dilakukan penambahan atom hidrogen polar dan non-polar (all hydrogen) dan melakukan pemisahan rantai-rantai yang tidak dipakai dalam hal ini protein $6 \mathrm{M} 2 \mathrm{~N}$ memiliki 4 rantai dan 4 ligan yaitu $\mathrm{A}, \mathrm{B}, \mathrm{C}$, dan D dimana hanya rantai $\mathrm{C}$ dan ligan WL1104 C yang digunakan dalam penelitian ini semua hal diatas dilakukan menggunakan perangkat lunak Studio Discovery Visualizer. Selanjutnya melakukan pengunduhan dari 51 senyawa uji flavonoid yang ada dialam daun jambu biji yang didapat dari pencarian dengan literatur penelitian yang dilakukan oleh (Anand et al., 2016; Sandra M. Barbalho, 2012; Habtemariam, 2019; Jiang et al., 2020) setelah pengunduhan selesai dilakukan skrining 5 aturan lipinski menggunakan marvin sketch maka didapatkan 31 senyawa uji yang lulus dari aturan 5 lipinskie ini sudah termasuk dengan senyawa pembanding lopinavir dan ligand native 3WL1104), beberapa senyawa yang tidak lulus dari skrining kebanyakan terkait bobot molekul, lipofilisitas, donor dan aseptor yang melebihi dari aturan lipinski. Setelah preparasi selesai maka dilakukanlah minimisasi energi menggunakan perangkat lunak Avogadro untuk ligand native, senyawa pembanding, dan senyawa uji parameter yang digunakan adalah medan gaya MMFF94. Sedangkan minimisasi untuk protein menggunakan perangkat lunak Swiss PDB viewer parameter medan gaya yang digunakan adalah gaya GROMOS 43B1.

3. Penambatan Protein ligan (Validasi Metode)

Penambatan ini dilakukan menggunakan perangkat lunak Autodock Tools dengan program tambahan Autodock4 dan Autogrid4, perlu diketahui bahwa pada perangkat lunak atau program ini ketika suatu senyawa telah dimasukan kedalam program ini dan telah melalui proses identifikasi dari torsi senyawa maka program ini akan menambahkan muatan Kollman dan Gastaiger secara otomatis pada protein dan ligan. Validasi metode ini dimulai dengan melakukan persiapan terhadap ligan dan protein ketika telah selesai maka langkah selanjutnya adalah melakukan pengaturan terhadap grid box, ukuran dari grid box yang digunakan dalam penelitian ini adalah $40 \times 40 \times 40$ dengan kordinat yang digunakan adalah $(X=-41.162, Y=-19.002, Z=56.921)$ dan jarak grid points $0.375 \AA$ A. Jenis metode dalam penambatan molekuler ini adalah penambatan fleksibel (flexible docking) dimana pada metode ini ligan dibuat sedemikian rupa fleksible dan protein dalam penelitian ini dibuat kaku (rigid). Algoritma pencarian dari penelitian ini dibuat sebanyak 100 kali konformasi dan pada tiap ligan diatur ukuran populasi Lamarckian Genetic Algorithm sebanyak 150 dengan jumlah evaluasi maksimum yaitu 2.500.000. dalam penelitian ini validasi dilakukan sebanyak empat kali terhadap ke empat rantai dan empat ligan dan didapatkan hasil yaitu ligand $\mathrm{C}$ dengan nilai terbaik. Validasi metode dari penambatan molekuler ini dikatakan baik dan valid jika nilai RMSD kurang dari $<2 \AA$. Visualisasi dan interkasi 2-Dimensi dari hasil penambatan molekuler yang dilakukan adalah menggunakan BIOVIA Discovery Studio Visualizerd dan LigPlot++ sedangkan PyMol digunakan untuk melakukan visualisasi secara 3-Dimensi.

4. Prediksi ADMET

ADMET adalah suatu bagian penting dalam proses prediksi farmakokinetika secara insilico yang dimana dalam proses penemuan obat baru tidak hanya dilihat dari kekuatan ligand dalam mengikat protein target, namun senyawa-senyawa juga harus dievaluasi dari segi farmakokinetik maupun toksisitas, dimana hal ini bertujuan untuk menentukan 
tingkat efektifitas dan keberhasilan dari terapeutiknya. Proses perjalanan obat didalam tubuh dimulai dari Absorbsi, Distribusi, Metabolisme dan Ekskresi (ADME) yang dimana prediksi dari ADME ini akan menggunakan $(\mathrm{PkCSM})$ merupakan situs berbasis web yang menyajikan prediksi terhadap sifat ADMET pada senyawa kimia baru dengan tingkatan akurasi yang cukup tinggi (Pires et al., 2015). Pada website PkCSM absorbsi dari suatu senyawa dinilai berdasarkan dari permeabilitas sel Caco-2, absorbsi pada usus manusia, dan permeabilitas senyawa pada kulit. Distribusi dilihat dari parameter sawar darah otak atau Blood Brain Barrier (logBB), permeabilitas Sistem Syaraf Pusat (SSP), dan volume distribusi keadaan tunak (VDss). Metabolisme diprediksi dengan melihat dari aktivitas senyawa terhadap sitokrom (CYP) dimana bebarap sitokrom yang dilihat adalah (CYP2D6, CYP3A4, CYP1A2, CYP2C19, CYP2C9, CYP2D6, dan CYP3A4) senyawa dilihat apakah sebagai substrat atau inhibitor. Prediksi ekskresi pada website ini dilihat dari total clearancedan renal OCT 2 sedangkan prediksi terakhir yaitu toksisitas dilihat dari toksisitas AMES, Inhibitor hERG, hepatotoksisitas, sensasi kulit, toksisitas pada Tetrahymena pyriformis dan toksisitas minnow.

\section{HASIL DAN PEMBAHASAN}

Molekuler docking (Penambatan Molekuler) adalah studi tentang bagaimana dua atau lebih struktur molekul (misalnya, obat dan enzim atau protein) cocok bersama-sama. Dalam definisi sederhana, penambatan Molekuler adalah teknik pemodelan molekuler yang digunakan untuk memprediksi bagaimana protein (enzim) berinteraksi dengan molekul kecil (ligan) (Roy et al., 2015).

\section{Validasi Metode}

Validasi metode dengan melakukan penambatan menggunakan masing-masing rantai contoh : Rantai A dengan Ligan A lalu diamati mana nilai RMSD yang paling rendah. RMSD adalah tolak ukur yang digunakan untuk mengevaluasi parameter proses docking yang dijalankan telah benar atau tidak, dan mendeskripsikan seberapa besar perubahan bentuk dari ligan native sebelum dan sesudah validasi metode dilakukan. Metode docking dikatakan valid dan benar adalah ketika nilai RMSD kurang dari $2 \AA$. Setelah dilakukan validasi dari ke empat rantai A, B, C, dan D dengan ligand A, B, C, D didapatkan hasil nilai RMSD terkecil yaitu pada rantai $\mathrm{C}$ dan Ligan $\mathrm{C}$ dengan nilai RMSD $1.709 \AA$.

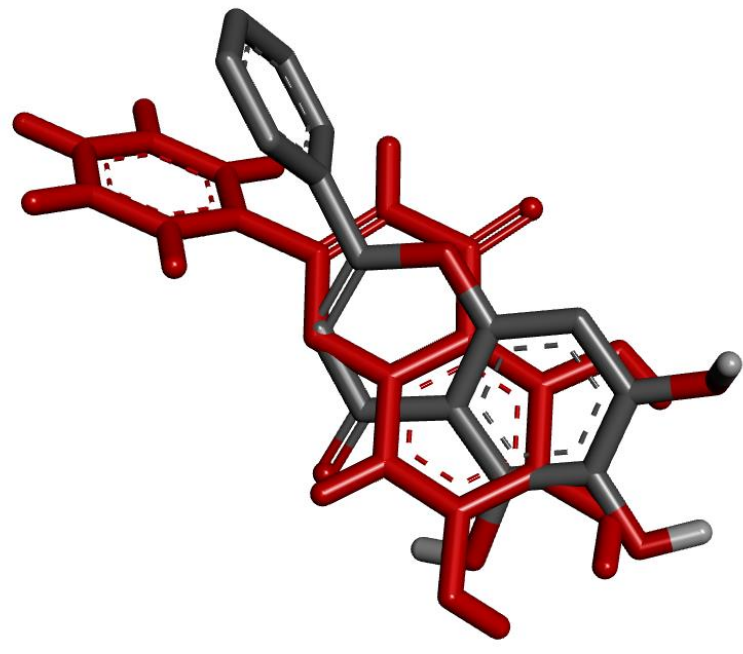


Gambar 1. Hasil visualisasi overlaping antara ligan native warna merah (co-cristal) dan yang berwarna abu-abu merah (hasil re-docking) dengan RMSD sebesar $1.709 \AA$

2. Ikatan Energi Bebas Gibbs $(\Delta \mathrm{G})$ Dan Konstanta Inhibisi (KI)

Hasil penambatan molekul yang bagus salah satunya dapat dilihat dengan membandingkan nilai energi binding atau energi bebas ikatan $(\Delta \mathrm{G})$ dan Konstanta Inhibisi (KI). Menurut (Arwansyah et al., 2014) energi binding menunjukan kekuatan dari ikatan antara ligan-reseptor semakin kecil nilai dari $\Delta \mathrm{G}$ interaksi antara ligan dan reseptor akan semakin stabil. Dimana jika nilai ikatan energi bebas semakin besar maka menunjukan kestabilan mengikat ligan dan protein atau reseptor yang cukup baik, berikut adalah hasil dari penambatan molekul dari 31 senyawa flavonoid dalam daun jambu biji. Senyawa pembanding Lopinavir dan ligan native $3 \mathrm{WL}$ pada protein $6 \mathrm{M} 2 \mathrm{~N}$ :

Tabel I. Nilai energi binding dan konstanta inhibisi dari penambatan molekuler pada protein $6 \mathrm{M} 2 \mathrm{~N}$

\begin{tabular}{|c|c|c|c|}
\hline No & Nama senyawa & $\begin{array}{l}\text { Energi } \\
\text { binding } \\
\text { (Kcal/mol) }\end{array}$ & Konstanta inhibisi \\
\hline 1 & Lopinavir & $-9,21$ & $178,81 \mathrm{nM}$ (nanomolar) \\
\hline 2 & $\begin{array}{l}\text { Ephicatecin-3-O- } \\
\text { Gallate }\end{array}$ & $-9,08$ & 221,92 nM (nanomolar) \\
\hline 3 & Glycitin & $-8,84$ & $333,46 \mathrm{nM}$ (nanomolar) \\
\hline 4 & Ononin & $-8,51$ & $573,51 \mathrm{nM}$ (nanomolar) \\
\hline 5 & Sissotrin & $-8,25$ & $895,26 \mathrm{nM}$ (nanomolar) \\
\hline 6 & Genistin & $-8,17$ & $1,03 \mathrm{uM}$ (micromolar) \\
\hline 7 & Guaijaverin & $-7,97$ & $1,45 \mathrm{uM}$ (micromolar) \\
\hline 8 & Esculin & $-7,73$ & 2,16 uM (micromolar) \\
\hline 9 & Glycitein & $-7,42$ & 3,64 uM (micromolar) \\
\hline 10 & Isohamnetin & $-7,30$ & 4,47 uM (micromolar) \\
\hline 11 & Ephicatecin & $-7,29$ & 4,54 uM (micromolar) \\
\hline 12 & Delphinidin & -7.28 & 4,58 uM (micromolar) \\
\hline 13 & Isofromononetin & $-7,27$ & 4,69 uM (micromolar) \\
\hline 14 & Catechin & $-7,25$ & $4,88 \mathrm{uM}$ (micromolar) \\
\hline 15 & Naringenin & $-7,25$ & 4,84 uM (micromolar) \\
\hline 16 & Phloridzin & $-7,20$ & 5,31 uM (micromolar) \\
\hline 17 & Formononetin & $-7,19$ & 5,38 uM (micromolar) \\
\hline 18 & Gallocatechin & $-7,13$ & 5,92 uM (micromolar) \\
\hline 19 & Daidzein & $-7,08$ & 6,43 uM (micromolar) \\
\hline 20 & Cyanidin & $-7,05$ & 6,85 uM (micromolar) \\
\hline 21 & Prunetin & $-6,95$ & $8,02 \mathrm{uM}$ (micromolar) \\
\hline 22 & Genistein & $-6,86$ & 9,34 uM (micromolar) \\
\hline 23 & Myricetin & $-6,79$ & $10,48 \mathrm{uM}$ (micromolar) \\
\hline 24 & Biochanin A & $-6,75$ & $11,31 \mathrm{uM}$ (micromolar) \\
\hline 25 & Apigenin & $-6,72$ & $11,95 \mathrm{uM}$ (micromolar) \\
\hline 26 & Quercetin & $-6,71$ & $12,03 \mathrm{uM}$ (micromolar) \\
\hline 27 & Leucocyanidin & $-6,67$ & $12,93 \mathrm{uM}$ (micromolar) \\
\hline
\end{tabular}




\begin{tabular}{llll}
28 & Ligand Native & $-6,54$ & $16,12 \mathrm{uM}$ (micromolar) \\
29 & Kaempferol & $-6,49$ & $17,44 \mathrm{uM}$ (micromolar) \\
30 & Phloretin & $-6,47$ & $17,97 \mathrm{uM}$ (micromolar) \\
31 & Tamarixetin & $-6,43$ & $19,29 \mathrm{uM}$ (micromolar) \\
32 & Morin & $-6,34$ & $22,45 \mathrm{uM}$ (micromolar) \\
33 & Gossypetin & $-6,31$ & $23,54 \mathrm{uM}$ (micromolar) \\
\hline
\end{tabular}

Dilihat berdasarkan nilai energi ikatan bebas paling kuat yaitu senyawa pembanding lopinavir dengan nilai $-9,21 \mathrm{kcal} / \mathrm{mol}$ namun senyawa ligan native $3 \mathrm{WL} 1104$ mendapatkan nilai energi ikatan bebas yang cukup rendah yaitu sebesar $-6,54 \mathrm{kcal} / \mathrm{mol}$. Sedangkan senyawa uji dengan energi ikatan bebas tertinggi yaitu Ephicatecin-3-Ogallate dengan free energy binding (ikatan energi bebas) sebesar $-9,08 \mathrm{kcal} / \mathrm{mol}$, Glycitin dengan free energy binding (ikatan energi bebas) sebesar $-8,84 \mathrm{kcal} / \mathrm{mol}$, dan ononin dengan free energy binding (ikatan energi bebas) sebesar $-8,51 \mathrm{kcal} / \mathrm{mol}$. Dengan kata lain dilihat dari senyawa uji nya Ephicatecin-3-O-gallate berpotensi sebagai kandidat penghambat dari 3CL pro. Tingginya nilai energi bebas ikatan $(\Delta \mathrm{G})$ Epicatechin-3-OGallate dapat disebabkan karena lebih kuatnya interaksi non-kovalen dari senyawa ini, hasil ini di dukung oleh penelitian (Jang et al., 2020) dimana dalam penelitian ini tidak menggunakan Ephicatecin-3-O-gallate namun menggunakan golongan catechin lainnya yaitu Epicatechin-3-O-Gallate secara signifikan menghambat 3CL-Protease dengan dosis tergantung, konsentrasi $\left(\mathrm{IC}_{50}\right)$ dari EGCG menggunakan AAT Program situs web Bioquest didapat $\mathrm{IC}_{50}$ untuk EGCG dari 7,58 $\mu \mathrm{g} / \mathrm{ml}$, hal ini dapat dikatakan bahwa senyawa golongan catechin dapat menghambat dari 3CL Protease.

Senyawa selanjut yang berpotensi untuk menghambat 3CL Protease adalah senyawa Glycitin dan ononin dimana senyawa ini merupakan senyawa golongan isoflavonoid yang energi ikatan bebas nya berada dibawah Epicatechin-3-O-Gallate dimana senyawa glycitin dan ononin ini dapat berpotensi juga sebagai inhibitor $3 \mathrm{Cl}$ pro, belum ada penelitian yang dapat menunjukan Glycitin dan ononin memiliki potensi dalam menghambat 3CL pro namun pada penelitian yang dilakukan oleh (Solnier \& Fladerer, 2020) mengatakan bahwa senyawa isoflavon salah satunya yaitu daidzein menunujkan penghambatan yang lemah terhadap SARS-CoV 3CL Protease namun secara struktural terkait dengan daidzein - terprenilasi pada C30, dan corylifol A yang diekstrak dari biji Cullen corylifolia, ditemukan memiliki potensi penghambatan yang baik terhadap SARSCoV PL pro.

Berdasarkan hasil diatas Ephicatecin-3-O-gallate, Glycitin dan Ononin merupakan senyawa yang baru diketahui dapat menghambat 3CL Protease, belum terdapat penelitian terdahulu yang menunjukan hasil yang sama dalam penambatan molekuler antara senyawa flavonoid dengan protein $6 \mathrm{M} 2 \mathrm{~N}$, sehingga sulit dalam mencari literatur pendukung hasil penelitian ini.

\section{Interaksi Residu Asam Amino}

Pengamatan dari interaksi residu asam amino dari intetarksi senyawa uji dengan protein terget ini bertujuan untuk melakukan identifikasi interaksi yang terjadi dan yang diduga berinterksi dalam munculnya efek farmakologi inhibitor 3CL Protease oleh senyawa uji. Beberapa jenis interaksi antara ikatan adalah interaksi ikatan hidrogen, interaksi ikatan hidrofobik, interaksi ikatan Van der Waals, interaksi ikatan elektrostatik dan interaksi ikatan halogen. Namun pada penelitian kali ini interaksi yang di tampilkan adalah conventional hydrogen bond (ikatan hidrogen konvensional) dan carbon hydrogen bond (ikatan hidrogen karbon). Ikatan hidrogen merupakan ikatan yang terkuat di antara ikatan non-kovalen lainnya namun ikatan hidrogen lebih lemah dibandingkan ikatan ion atau ikatan kovalen oleh karena itu ikatan hidrogen paling banyak tersebar dalam menghasilkan aktivitas farmakologi, sehingga penting untuk dilakukan analisis terhadap 
ikatan hidrogen apa saja yang terbentuk, berikut adalah hasil dari analisis interkasi residu asam amino pembentuk ikatan hidrogen :

Tabel II. Data Interaksi Residu Asam Amino Pembentuk Ikatan Hidrogen

\begin{tabular}{|c|c|c|c|}
\hline No & Senyawa & Conventional hydrogen bond & $\begin{array}{l}\text { Carbon hydrogen } \\
\text { bond }\end{array}$ \\
\hline 1 & Ligand native & $\begin{array}{l}\text { GLY } 143(1,99) \text {, GLY } 143(2,23), \text { LEU } \\
141(1,67) \text {, HIS } 163(2,07)\end{array}$ & - \\
\hline 2 & Lopinavir & THR $25(2,93)$, ASN $145(3,13)$ & - \\
\hline 3 & Apigenin & ASP $187(2,93)$, GLU $166(1,91)$ & HIS $41(3,60)$ \\
\hline 4 & Biochanin A & $\begin{array}{l}\text { GLY } 143(1,67), \text { MET } 49(2,05) \\
\text { LEU } 141(1,64) \text {, GLY } 143(2,47) \text {, CYS }\end{array}$ & LEU $141(3,01)$ \\
\hline 5 & Catechin & $\begin{array}{l}145(2,74), \text { GLU } 166(1,61), \text { GLU } 166 \\
(2,43), \text { ARG } 188(2,50) \\
\text { ARG } 188(2,19), \text { GLU } 166(2,21), \text { CYS } \\
145(2,86), \text { LEU } 141(1,95), \text { SER } 144 \\
(2,12)\end{array}$ & - \\
\hline 7 & Daidzein & $\begin{array}{l}\text { THR } 190(2,10) \text {, THR } 190(1,90), \text { GLN } \\
192(2,36), \text { LEU } 141(2,18) \\
\text { LEU 141 }(1,94) \text {, GLY } 143(2,45), \text { SER }\end{array}$ & - \\
\hline 8 & Delphinidin & $\begin{array}{l}144(2,94), \text { HIS } 163(1,77), \text { CYS } 145 \\
(2,89), \text { GLU } 166(2,24), \text { ARG } 188(2,18) \\
\text { ARG } 188(2,48), \text { GLU } 166(1,59), \text { GLU }\end{array}$ & - \\
\hline 9 & Ephicatecin & $\begin{array}{l}166(2,38), \text { CYS } 145(2,72), \text { CYS } 145 \\
(3,41), \text { LEU } 141(1,66)\end{array}$ & - \\
\hline 10 & $\begin{array}{l}\text { Epicatechin-3- } \\
\text { O-Gallate }\end{array}$ & $\begin{array}{l}\text { HIS } 41(1,96) \text {, MET } 49(2,90) \text {, GLU } 166 \\
(2,26) \text {, GLN } 192(2,27) \text {, THR } 190(2,08) \text {, } \\
\text { THR } 190(2,17) \text {, SER } 144(2,10) \text {, LEU } \\
141(2,21)\end{array}$ & - \\
\hline 11 & Esculin & $\begin{array}{l}190(1,90), \text { GLU } 166(1,67), \text { GLU } 166 \\
(1,86), \text { GLU } 166(2,13), \text { HIS } 164(1,89)\end{array}$ & - \\
\hline 12 & Formononetin & $\begin{array}{l}\text { GLU } 166(1,90), \text { GLN } 192 \text { (2,23), THR } \\
190(1,86)\end{array}$ & - \\
\hline 13 & Gallocatechin & $\begin{array}{l}\text { ARG } 188(2,39), \text { GLU } 166(1,61), \text { GLU } \\
166(2,38), \text { CYS } 145(2,82), \text { LEU } 141 \\
(1,89), \text { LEU } 141(2,38), \text { GLY } 143(2,48)\end{array}$ & - \\
\hline 14 & Genistein & $\begin{array}{l}\text { LEU } 141(1,66) \text {, GLY } 143(2,44) \text {, CYS } \\
145(2,89), \text { GLU } 166(1,80), \text { ARG } 188 \\
(1,96)\end{array}$ & - \\
\hline 15 & Genistin & $\begin{array}{l}\text { GLU } 166(1,93), \text { GLU } 166(2,90), \text { LEU } \\
141(1,79) \text {, LEU } 141(1,95) \text {, CYS } 145 \\
(2,37) \text {, CYS } 145(2,57), \text { SER } 144(1,81) \text {, } \\
\text { ASP } 187(2,90)\end{array}$ & - \\
\hline 16 & Glycitein & $\begin{array}{l}\text { THR } 190(1,81) \text {, THR } 190(2,03) \text {, GLN } \\
192(2,42), \text { LEU } 141(2,16), \text { GLY } 143 \\
(2,25)\end{array}$ & - \\
\hline 17 & Glycitin & $\begin{array}{l}\text { GLU } 166(1,85), \text { GLU } 166(2,84), \text { ASN } \\
142(2,42), \text { LEU } 141(1,76), \text { LEU } 141 \\
(1,85), \text { CYS } 145(2,61), \text { ASP } 187(2,77)\end{array}$ & - \\
\hline
\end{tabular}


18 Gossypetin

19 Guaijaverin

20 Isofromononetin

21 Isohamnetin

22 Kaempferol
GLU 166 (2,10), CYS 145 (2,75), LEU $141(1,86)$, SER $144(2,16)$

ASN $142(2,22)$, HIS $163(2,08)$, THR 26 $(1,86)$, THR $26(1,95)$, THR $26(2,44)$

GLY 143 (1,90), GLU $166(1,83)$, ARG $188(2,02)$

LEU 141 (1,99), SER 144 (2,12), GLY 143 (2,03), CYS 145 (2,84), GLU 166 $(2,20)$

GLU 166 (2,26), CYS $145(2,84)$, GLY $143(2,50)$, LEU $144(1,65)$
GLN $189(3,38)$

MET $165(3,12)$, LEU $141(2,97)$

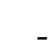

GLU 166 (1,71), GLU $166(2,40)$, CYS

23 Leucocyanidin $145(2,56)$, LEU $141(1,80)$, SER 144 $(1,74)$

24 Morin

GLY 143 (2,01), THR $26(1,97)$, ASP 187 $(2,77)$, HIS $164(2,22)$, HIS $164(2,50)$

HIS $163(1,88)$, LEU $141(1,89)$, GLY

25 Myricetin

143 (2,49), CYS 145 (2,86), GLU 166 $(2,21)$

THR 190 (2,02), GLN 192 (2,05), GLU

$26 \quad$ Naringenin

166 (2,07), HIS 163 (2,03), ASN 142 $(1,95)$

CYS 44 (1,99), CYS 145 (2,79), GLY 143

27 Ononin

$(2,17)$, LEU $141(2,08)$, LEU $141(1,78)$,

GLU $166(2,07)$, GLU $166(2,80)$

GLN $189(3,29)$

ASP 187 (2,91), ASN 142 (2,74), GLY

$28 \quad$ Phloretin

143 (1,85), SER 144 (2,58), HIS 163

$(1,88)$, HIS $164(2,10)$, GLU $166(2,93)$

GLU $166(2,25)$, GLU $166(2,97)$, THR

$29 \quad$ Phloridzin

26 (2,69), CYS 145 (2,28), CYS 44 $(2,24)$, MET 49 (2,27), GLY $143(2,57)$,

LEU $141(1,70)$

$30 \quad$ Prunetin

THR 190 (2,06), GLN 192 (2,28), GLU $166(1,67)$

$31 \quad$ Quercetin

GLU 166 (2,22), CYS 145 (2,78), LEU

$141(1,87)$, SER $144(2,14)$

PHE 140 (2,86), GLU 166 (2,11), GLU

32 Sissotrin

166 (1,77), GLU $(1,91)$, GLY $143(1,90)$

CYS 44 (1,92), ASP 187 (2,54), GLU 166 $(1,80)$

GLN $189(3,29)$

MET $165(2,89)$,

CYS $44(4,73)$

MET 49 (2,92), ASP $187(3,12)$

MET $49(2,83)$

Berdasarkan tabel diatas terdapat 19 asam amino pembentuk ikatan hidrogen. Asam amino yang paling banyak berkontribusi membentuk ikatan hidrogen antara protein dan ligand adalah GLU 166 yaitu sebanyak 37 interaksi, kemudian disusul oleh LEU 141 sebanyak 25 interaksi, CYS 145 sebanyak 18 interaksi dan GLY 143 sebanyak 17 interaksi.

Penelitian yang dilakukan oleh (Pintilie et al., 2020) melakukan penambatan Molekuler untuk mendapatkan prediksi akurat dari konformasi yang dioptimalkan untuk ligan dan target protein untuk membentuk kompleks yang stabil. Protein yang diigunakan adalah SARS-CoV-2 3CL pro (PDB ID: 6M2N). Pose docking dari co-crystallized 3WL yang berinteraksi dengan amino residu asam dari situs aktif dan ikatan hidrogen yang 
dibuat dengan GLU 166 (3,016 ̊), GLY 143 (3,104 Å dan 2,969 ̊) dan ASN 142 (3,341 $\AA$ A). Dari penelitian dari diatas bahwa GLU 166, GLY 143 dan ASN 142 asam amino berikut sesuai dengan penelitian ini. Sedangkan menurut penelitian yang dilakukan oleh (Saif et al., 2020) sisi aktif dari residu berupa asam amino residu Glu166 menunjukkan jarak rata-rata yang hampir konsisten dengan deviasi rendah. Namun, 4 ikatan-H lainnya dengan Thr190, Asn142 dan Glu166 awalnya memiliki jarak rata-rata yang sangat besar tetapi setelah sekitar $18 \mathrm{~ns}$ itu berkurang dan distabilkan. Protease SARS-CoV-2 secara istimewa membelah substratnya setelah Gln yang mengikuti Leu dan sebelum asam amino Ser atau Ala atau Gly (Leu-Gln Ser / Ala / Gly). Asam amino Gln, pada posisi substrat, adalah asam amino dengan rantai samping yang relatif panjang yang mengarah ke gugus amida polar dengan kemungkinan donor / akseptor hidrogen. Hal ini menunjukan bahwa interaksi residu asam amino yang terbentuk sesuai dengan literatur penelitian terdahulu yang menggunakan protein $6 \mathrm{M} 2 \mathrm{~N}$ sehingga dapat dikatakan bahwa penelitian ini sudah benar terkait hasilnya karena residu asam amino yang didapat dengan diliteratur sama.

(A)
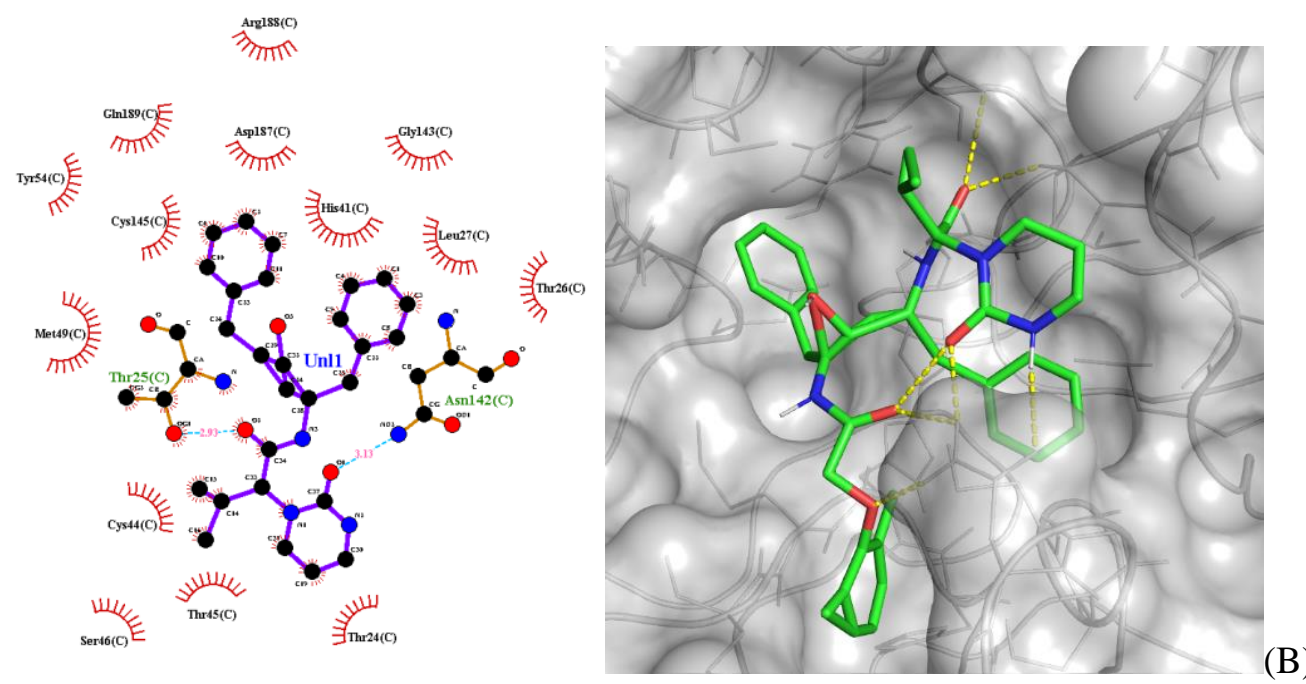

(B)

Gambar 2. (A) Hasil interaksi 2-Dimensi senyawa pembanding lopinavir menggunakan LigPlot++ dan (B) visualisasi 3-Dimensi senyawa pembanding lopinavir pada sisi aktif protein 6M2N menggunakan PyMOL
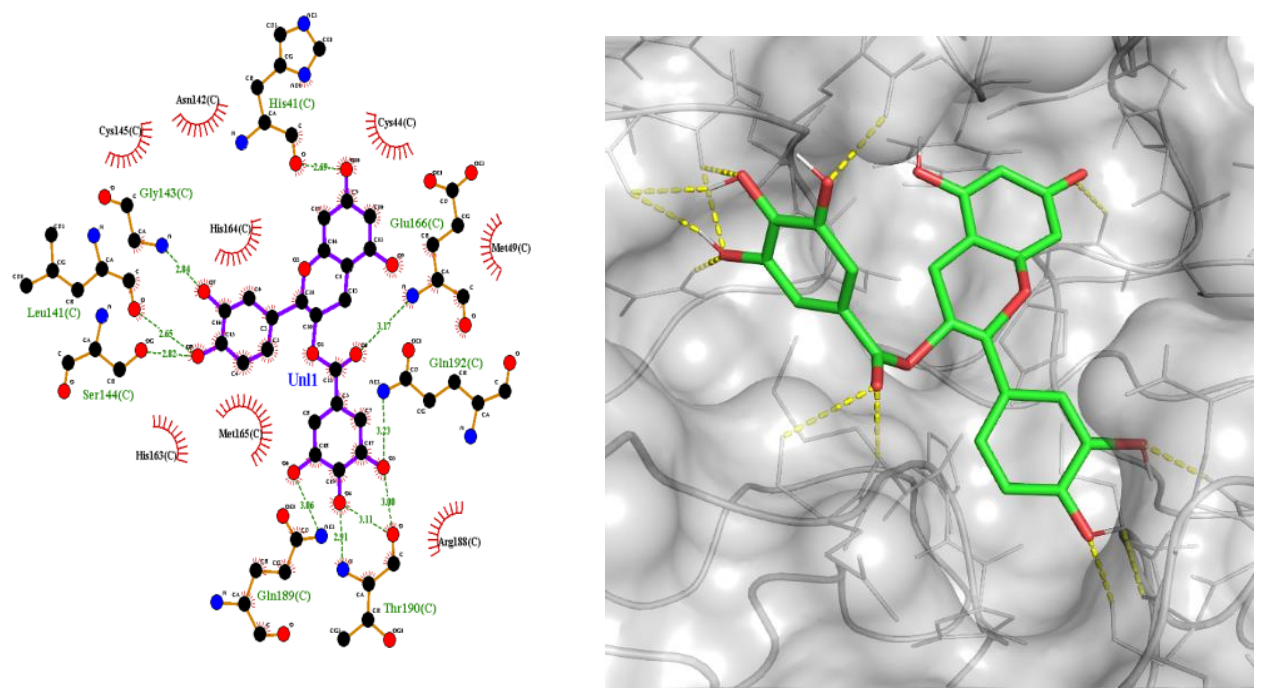

(A)

Gambar 3. (A) Hasil interaksi 2-Dimensi senyawa epicatechin-3-O-gallate menggunakan LigPlot++ dan (B) visualisasi 3-Dimensi senyawa epicatechin-3-O-gallate pada sisi aktif protein 6M2N menggunakan PyMOL 
(A)
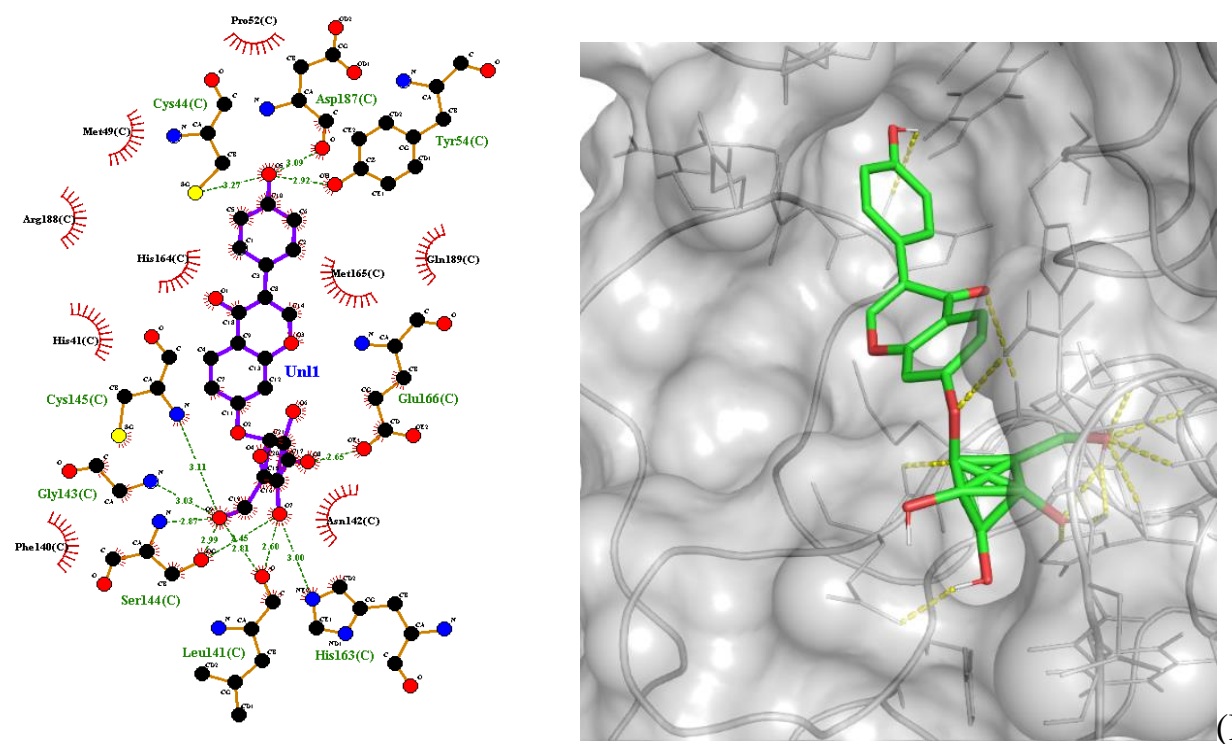

(B)

Gambar 4. (A) Hasil interaksi 2-Dimensi senyawa glycitin menggunakan LigPlot++ dan (B) visualisasi 3-Dimensi senyawa glycitin pada sisi aktif protein $6 \mathrm{M} 2 \mathrm{~N}$ menggunakan PyMOL
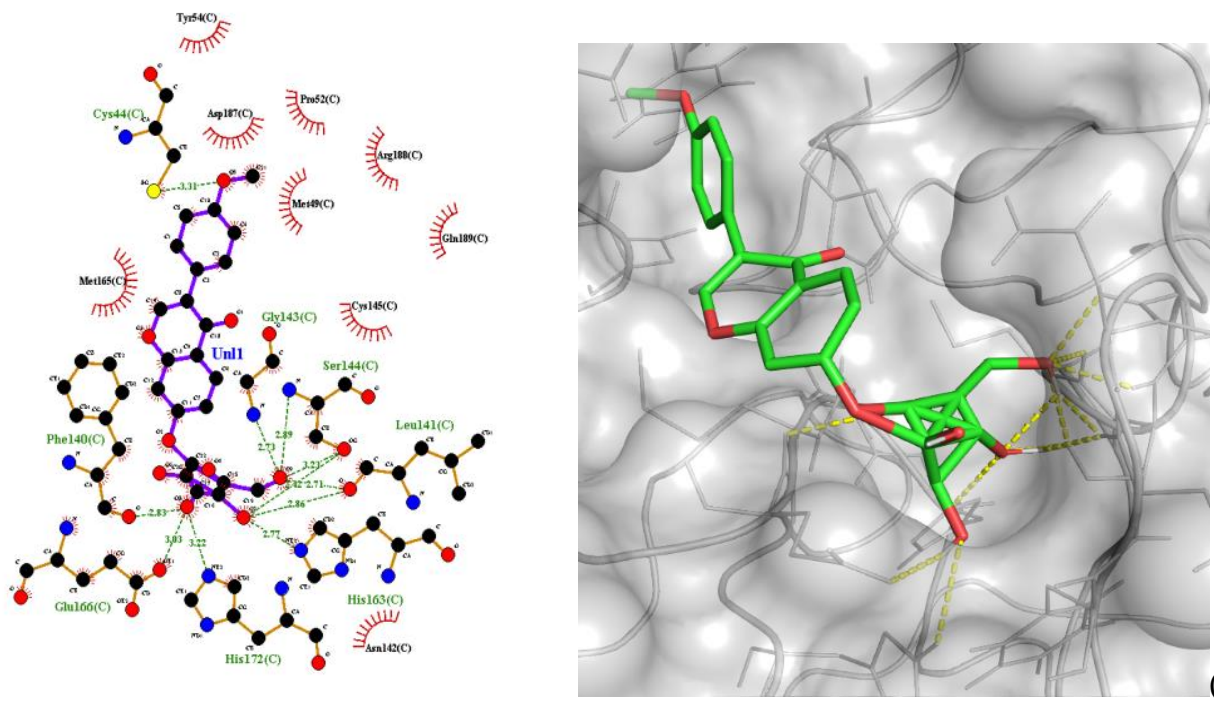

(B)

Gambar 5. (A) Hasil interaksi 2-Dimensi senyawa ononin menggunakan LigPlot++ dan (B) visualisasi 3-Dimensi senyawa ononin pada sisi aktif protein $6 \mathrm{M} 2 \mathrm{~N}$ menggunakan PyMOL

4. Prediksi ADMET

Prediksi dari ADMET (Absorbsi, Distribusi, Metabolisme, Ekskresi, Toksisitas) pada penelitian ini menggunakan PkCSM dimana pada situs ini akan menyajikan hasil prediksi dari ADMET pada senyawa kimia yang di uji dengan tingkat ketepatan atau akurasi yang sangat tinggi, seluruh senyawa pada penelitian ini akan diskrining terkait ADMET melalui website PkCSM dan berikut adalah prediksi ADMET dari 1 senyawa pembanding lopinavri dan 3 senyawa penambatan molekuler terbaik yaitu epicatechin-3O-gallate, glycitin, dan ononin : 
Tabel III. Nilai energi binding dan konstanta inhibisi dari penambatan molekuler pada protein $6 \mathrm{M} 2 \mathrm{~N}$

\begin{tabular}{|c|c|c|c|c|c|c|}
\hline \multirow{2}{*}{ ADMET } & \multirow{2}{*}{ Parameter } & \multirow{2}{*}{$\begin{array}{c}\begin{array}{c}\text { Senyawa } \\
\text { Pembanding }\end{array} \\
\text { Lopinavir }\end{array}$} & \multicolumn{3}{|c|}{ Senyawa Uji } & \multirow{2}{*}{ Keterangan } \\
\hline & & & $\begin{array}{l}\text { Epicatechin- } \\
\text { 3-O-gallate }\end{array}$ & Glycitin & Ononin & \\
\hline \multirow{3}{*}{ 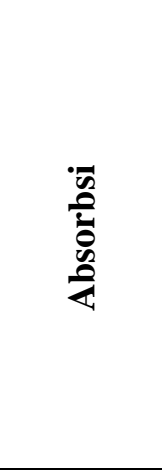 } & $\begin{array}{l}\text { Permeabilitas pada } \\
\text { Caco2 } \\
\text { Numerik (log Papp in } 10^{-} \\
\left.{ }^{6} \mathrm{~cm} / \mathrm{s}\right)\end{array}$ & 0,79 & $-1,733$ & 0,293 & 0,315 & $\begin{array}{l}\text { Permeabilitas } \\
\text { tinggi }<0.90\end{array}$ \\
\hline & $\begin{array}{l}\text { Absorbsi pada usus } \\
\text { manusia } \\
\text { Numerik (\% Absorbed) }\end{array}$ & $71.951 \%$ & $57.107 \%$ & $53.328 \%$ & $54.212 \%$ & $\begin{array}{l}\text { Absorpsi buruk } \\
\text { jika }<30 \%\end{array}$ \\
\hline & $\begin{array}{l}\text { Permeabilitas pada kulit } \\
\text { Numerik (log Kp) }\end{array}$ & $-2,731$ & $-2,735$ & $-2,735$ & $-2,735$ & $\begin{array}{l}\text { Permeabilitas } \\
\text { kulit rendah jika } \\
\log \mathrm{Kp}>-2.5\end{array}$ \\
\hline \multirow{3}{*}{ 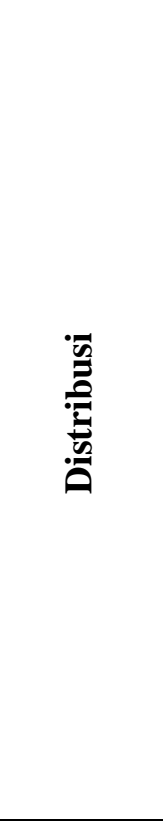 } & $\begin{array}{l}\text { VDss (human) } \\
\text { Numerik }(\log \mathrm{L} / \mathrm{kg})\end{array}$ & $-0,26$ & 0,604 & 0,422 & $-0,247$ & $\begin{array}{l}\text { VDss rendah jika } \\
\log <-0.15 \\
\text { VDss tinggi jika } \\
\log >0.45\end{array}$ \\
\hline & $\begin{array}{l}\text { BBB permeability } \\
\text { Numerik (log BB) }\end{array}$ & $-0,879$ & 0,604 & $-1,193$ & $-1,232$ & $\begin{array}{l}\text { Absropsi pada } \\
\text { otak baik jika } \\
\operatorname{logBB}>0.3 \\
\text { Absropsi pada } \\
\text { otak buruk jika } \\
\operatorname{logBB}<-1\end{array}$ \\
\hline & $\begin{array}{l}\text { CNS permeability } \\
\text { Numerik (log PS) }\end{array}$ & $-2,441$ & $-3,983$ & $-3,951$ & $-3,909$ & $\begin{array}{l}\text { Dapat } \\
\text { berpenetrasi pada } \\
\text { CNS jika Log PS } \\
>-2 \\
\text { Tidak dapat } \\
\text { berpenetrasi pada } \\
\text { CNS jika Log PS } \\
<-3\end{array}$ \\
\hline \multirow{7}{*}{ 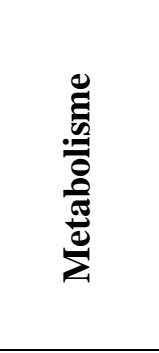 } & substrat CYP2D6 & Tidak & Tidak & Tidak & Tidak & \\
\hline & substrat CYP3A4 & $\mathrm{Ya}$ & Ya & Tidak & Tidak & \\
\hline & inhibitior CYP1A2 & Tidak & Tidak & Tidak & Tidak & \\
\hline & inhibitior CYP2C19 & $\mathrm{Ya}$ & Tidak & Tidak & Tidak & \\
\hline & inhibitior CYP2C9 & Ya & Tidak & Tidak & Tidak & \\
\hline & inhibitior CYP2D6 & Tidak & Tidak & Tidak & Tidak & \\
\hline & inhibitior CYP3A4 & $\mathrm{Ya}$ & Tidak & Tidak & Tidak & \\
\hline \multirow{2}{*}{ 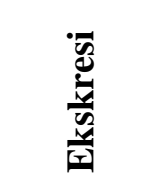 } & $\begin{array}{l}\text { Total Clearance } \\
\text { Numerik }(\log \mathrm{ml} / \mathrm{min} / \mathrm{kg})\end{array}$ & 0,514 & 0,549 & 0,522 & 0,522 & \\
\hline & Renal OCT2 substrat & Tidak & Tidak & Tidak & Tidak & \\
\hline \multirow{2}{*}{ 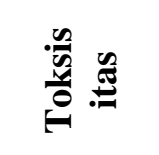 } & AMES toxicity & Tidak & Tidak & Tidak & Tidak & \\
\hline & $\begin{array}{l}\text { Max. tolerated dose } \\
\text { (human) }\end{array}$ & 0,102 & 0,47 & 0,526 & 0,405 & \\
\hline
\end{tabular}




\begin{tabular}{|c|c|c|c|c|c|}
\hline inhibitor hERG I & Tidak & Tidak & Tidak & Tidak & \\
\hline inhibitor hERG II & Ya & Ya & Tidak & Tidak & \\
\hline Hepatotoxicity & Ya & Tidak & Tidak & Tidak & \\
\hline Skin Sensitisation & Tidak & Tidak & Tidak & Tidak & \\
\hline $\begin{array}{l}\text { T.Pyriformis toxicity } \\
\text { Numerik (log ug/L) }\end{array}$ & Toksik & Toksik & Toksik & Toksik & $\begin{array}{l}\text { Senyawa toksik } \\
\text { jika Log > } 0.5 \\
\text { ug/L }\end{array}$ \\
\hline $\begin{array}{l}\text { Minnow toxicity } \\
\text { Numerik }(\log \mathrm{mM})\end{array}$ & Rendah & Rendah & Rendah & Rendah & $\begin{array}{l}\text { Toksisitas } \\
\text { senyawa akutnya } \\
\text { tinggi jika Log < } \\
-0.3\end{array}$ \\
\hline
\end{tabular}

Dilihat dari data diatas senyawa pembanding lopinavir serta senyawa uji epicatechin-3-O-gallate, glycitin dan ononin memiliki permeabilitas atau kemampuan menembus sel Caco-2 yang rendah, namun diprediksi pada PkCSM empat senyawa ini memiliki absorbsi yang bagus pada usus manusia sehingga semua senyawa ini dapat diserap melalui saluran cerna manusia yaitu usus, tiga senyawa uji yaitu epicatechin-3-O-gallate, glycitin dan ononin memiliki hasil prediksi permeabilitas pada kulit yang tinggi ini menunjukan bahwa tiga senyawa ini dapat dibuat dalam bentuk sediaan luar atau topikal dengan rute pemberian yaitu transdermal. Kemudian pada prediksi distribusi dari ke empat senyawa uji ini termasuk dengan senyawa pembanding hanya epicatechin-3-O-gallate yang memiliki nilai VDss yang tinggi melebihi log 0.45 hal ini menggambarkan bahwa senyawa epicatechin-3-O-gallate ini akan terdistribusi lebih banyak didalam jaringan sedangkan jika nilai VDss yang rendah kemungkinan obat atau senyawa itu akan terdistribusi lebih banyak diluar jaringan. Prediksi empat senyawa ini dapat menembus sawar darah otak hanya epicatechin-3-O-gallate yang memiliki nilai yang tinggi sehingga kemungkinan senyawa ini dapat menjadi kandidat obat dengan target obat menembut sawar darah orak (blood brain barrier), untuk sistem saraf pusat dari ke empat senyawa dengan nilai penambatan tertinggi dalam penelitian ini semua memiliki nilai yang rendah sehingga tidak cocok ditargetkan sebagai kandidat obat yang bekerja di sistem syaraf pusat.

Prediksi metabolisme dari empat senyawa uji penelitian ini, senyawa pembanding lopinavir diperkirakan menghambat enzim CYP2C19, CYP2C9, CYP3A4 sehingga dapat disimpulkan bahwa senyawa lopinavir ini menghambat dari metabolisme yang dilakukan oleh sitokrom P450, sedangkan senyawa epicatechin-3-O-gallate merupakan senyawa yang diprediksi sebagai substrat dari enzim CYP3A4 sehingga dapat di metabolisme oleh sitokrom utama CYP3A4 senyawa glycitin dan ononin disini diprediksi dapat dimetabolisme dengan baik oleh sitokrom P450 dan mudah untuk dieksresikan.

Prediksi eksresi dari empat senyawa uji pada penelitian ini menunjukan bahwa epicatechin-3-O-gallate memiliki nilai total klirens yang tinggi sehingga disimpulkan bahwa senyawa epicatechin-3-O-gallate ini memiliki laju eksresi yang besar dari pada ketiga senyawa lainnya, ke empat senyawa uji ini juga diprediksi bukan merupakan renal OCT2 substrat yang dimana hal ini menunjukan bahwa ke empat senyawa ini tidak menimbulkan efek toksi jika dibuat dalam sediaan oral yang dikonsumsi bersamaan dengan renal OCT2 inhibitor.

Lopinavir, epicatechin-3-O-gallate, glycitin, dan ononin diprediksi tidak menimbulkan mutasi dilihat dari prediksi uji AMES, sedangkan terkait dengan hepatotoksik hanya senyawa pembanding lopinavir yang diprediksi dapat merusak hati. Dalam prediksi inhibitor hERG senyawa lopinavir dan epicatechin-3-O-gallate merupakan senyawa yang diprediksi sebagai inhibitor hERG (efek sampingnya berupa gangguan pada jantung), ke empat senyawa ini memiliki toksisitas pada protozoa T.Pyriformis, namun ke empat senyawa ini memiliki nilai yang rendah terhadap toksisitas nya terhadap lingkungan yang tunjukan pada uji toksisitas Minnow. 


\section{KESIMPULAN}

Pada studi penambatan molekul senyawa flavonoid dalam daun jambu biji (Psidium guajava L.) terhadap protein dengan PDB ID : 6M2N sebagai inhibitor 3CL Protease, diperoleh hasil energi ikatan bebas $(\Delta \mathrm{G})$ dari tiga senyawa uji terbaik yaitu Epicatechin-3-OGallate dengan nilai sebesar $-9,08 \mathrm{kcal} / \mathrm{mol}$, Glycitin dengan nilai sebesar $-8,84 \mathrm{kcal} / \mathrm{mol}$, dan senyawa ononin dengan nilai sebesar $-8,51 \mathrm{kcal} / \mathrm{mol}$. Residu asam amino yang paling banyak berperan dalam terbentuknya ikatan hidrogen adalah residu asam amino GLU 166 , LEU 141, dan GLY 143 residu asam amino tersebut banyak berkontribusi dalam pembentukan ikatan hidrogen pada pengikatan senyawa pada protein 3CL Protease. Secara keseluruhan dapat disimpulkan bahwa tiga senyawa uji flavonoid yaitu epicatechin-3-OGallate, glycitin, dan ononin memiliki potensi aktivitas sebagai inhibitor dari 3CL Protease dari SARS-CoV-2.

\section{DAFTAR PUSTAKA}

Anand, V., Manikandan, Kumar, V., Kumar, S., Pushpa, \& Hedina, A. (2016). Phytopharmacological overview of Psidium guajava Linn. Pharmacognosy Journal, 8(4), 314-320. https://doi.org/10.5530/pj.2016.4.3

Arwansyah, Ambarsari, L., \& Sumaryada, T. I. (2014). Simulasi Docking Senyawa Kurkumin Dan Analognya Sebagai Inhibitor Enzim 12-Lipoksigenase. Current Biochemistry, 1(in silico), 36-39.

Bhatt, T., Kumar, V., Pande, S., Malik, R., Khamparia, A., \& Gupta, D. (2021). A Review on COVID-19. Studies in Computational Intelligence, 924(April), 25-42. https://doi.org/10.1007/978-3-030-60188-1_2

Habtemariam, S. (2019). Medicinal Foods as Potential Therapies for Type-2 Diabetes and Associated Diseases: The Chemical and Pharmacological Basis of their Action - 1st Edition. https://doi.org/10.1016/C2018-0-02257-4

Helmy, Y. A., Fawzy, M., Elaswad, A., Sobieh, A., Kenney, S. P., \& Shehata, A. A. (2020). The COVID-19 Pandemic: A Comprehensive Review of Taxonomy, Genetics, Epidemiology, Diagnosis, Treatment, and Control. Journal of Clinical Medicine, 9(4), 1225. https://doi.org/10.3390/jcm9041225

Huang, R., Zhu, L., Xue, L., Liu, L., Yan, X., Wang, J., Zhang, B., Xu, T., Ji, F., Zhao, Y., Cheng, J., Wang, Y., Shao, H., Hong, S., Cao, Q., Li, C., Zhao, X.-A., Zou, L., Sang, D., ... Wu, C. (2020). Clinical findings of patients with coronavirus disease 2019 in Jiangsu province, China: A retrospective, multi-center study. PLoS Neglected Tropical Diseases, 14(5), e0008280. https://doi.org/10.1371/journal.pntd.0008280

Jang, M., Park, Y. I., Cha, Y. E., Park, R., Namkoong, S., Lee, J. I., \& Park, J. (2020). Tea Polyphenols EGCG and Theaflavin Inhibit the Activity of SARS-CoV-2 3CL-Protease in Vitro. Evidence-Based Complementary and Alternative Medicine, 2020. https://doi.org/10.1155/2020/5630838

Jiang, L., Lu, J., Qin, Y., Jiang, W., \& Wang, Y. (2020). Antitumor effect of guava leaves on lung cancer: A network pharmacology study. Arabian Journal of Chemistry, 13(11), 7773-7797. https://doi.org/10.1016/j.arabjc.2020.09.010

Joseph, B., \& Priya, M. (2011). Review on Nutritional, Medicinal and Pharmacological properties of Guava (Psidium guajava Linn.). International Journal of Pharma and Biosciences, 2, 53-69.

Kakodkar, P., Kaka, N., \& Baig, M. (2020). A Comprehensive Literature Review on the Clinical Presentation, and Management of the Pandemic Coronavirus Disease 2019 
(COVID-19). Cureus, 2019(4). https://doi.org/10.7759/cureus.7560

Panche, A. N., Diwan, A. D., \& Chandra, S. R. (2016). Flavonoids: An overview. Journal of Nutritional Science, 5. https://doi.org/10.1017/jns.2016.41

Pintilie, L., Tanase, C., \& Mohapatra, R. K. (2020). Molecular Docking Studies on Synthetic Therapeutic Agents for COVID-19. Chemistry Proceedings, 3(1), 46. https://doi.org/10.3390/ecsoc-24-08352

Pires, D. E. V, Blundell, T. L., \& Ascher, D. B. (2015). pkCSM: Predicting Small-Molecule Pharmacokinetic and Toxicity Properties Using Graph-Based Signatures. Journal of Medicinal Chemistry, 58(9), 4066-4072. https://doi.org/10.1021/acs.jmedchem.5b00104

Prajapat, M., Sarma, P., Shekhar, N., Avti, P., Sinha, S., Kaur, H., Kumar, S., Bhattacharyya, A., Kumar, H., Bansal, S., \& Medhi, B. (2020). Drug targets for corona virus: A systematic review. Indian Journal of Pharmacology, 52(1), 56-65. https://doi.org/10.4103/ijp.IJP_115_20

Purwaniati, P., \& Asnawi, A. (2020). Target Kerja Obat Covid-19: Review. Jurnal Farmagazine, 7(2), 30. https://doi.org/10.47653/farm.v7i2.172

Rauf, A., Abu-izneid, T., Olatunde, A., Khalil, A. A., Alhumaydhi, F. A., Tufail, T., Shariati, M. A., \& Rebezov, M. (2020). COVID-19 Pandemic: Epidemiology, Etiology, Conventional and Non-Conventional Therapies.

Roy, K., Kar, S., \& Das, R. (2015). Understanding the Basics of QSAR for Applications in Pharmaceutical Sciences and Risk Assessment. In Understanding the Basics of QSAR for Applications in Pharmaceutical Sciences and Risk Assessment.

Saif, R., Raza, M. H., Rehman, T., Zafar, M. O., Zia, S., \& Qureshi, A. R. (2020). Molecular Docking of Olea europaea and Curcuma Longa Compounds as Potential Drug Agents for Targeting Main-Protease of SARS-nCoV2. ChemRxiv, 1-16. https://doi.org/10.26434/chemrxiv.13246739.v1

Sandra M. Barbalho. (2012). Psidium Guajava (Guava): A Plant of Multipurpose Medicinal Applications. https://doi.org/10.4172/2167-0412.1000104

Solnier, J., \& Fladerer, J. P. (2020). Flavonoids: A complementary approach to conventional therapy of COVID-19? Phytochemistry Reviews, 6. https://doi.org/10.1007/s11101020-09720-6

Tallei, T. E., Tumilaar, S. G., Niode, N. J., Fatimawali, Kepel, B. J., Idroes, R., Effendi, Y., Sakib, S. A., \& Emran, T. Bin. (2020). Potential of Plant Bioactive Compounds as SARS-CoV-2 Main Protease (Mpro) and Spike (S) Glycoprotein Inhibitors: A Molecular Docking Study. Scientifica, 2020. https://doi.org/10.1155/2020/6307457 
